\begin{tabular}{lccc} 
VERSITA & GOSPODARKA & SUROWCAMI & MINERALNYMI \\
\hline \multirow{2}{*}{ Tom 29} & 2013 & Zeszyt 1 \\
& & DOI 10.2478/gospo-2013-0003 &
\end{tabular}

\title{
Benchmarking for Major Producers of Limestone in the Czech Republic
}

\section{Introduction}

The success of a mining company enterprise depends on its managers' abilities to make the right decisions. Such decision-making is, among other things, reliant upon the information at the disposal of the company managers.

Information plays a key role in the decision-making processes. The human factor of these processes - a manager - plays no less important role, and his/her discretion is of major importance with regards to information collection and processing (Fotr 2003). Also, buttressing tools of decision-making processes play their own, important role. This especially concerns decision-making methods and methods that can provide relevant information. The authors of this study maintain that benchmarking is one of such methods of relevant information gathering. Peter Drucker describes benchmarking as a tool of comparing one's own performance to the best performer in the field (Drucker 1999). In particular, the conclusions of such comparative exercises provide for the formulation of management and enterprise strategies for possible success. As such, benchmarking represents a precious tool in strategic decision-making processes. This is consistent with the view of Robert B. Pojasek who understands benchmarking as something that can identify performance differences. As he indicated, "Benchmarking measures your processes against the practices of other

* Ing. Ph.D., *** Ing., Institute of Economics and Management Systems, Faculty of Mining and Geology, VŠB - Technical University of Ostrava, Czech Republic; e-mail: michal.vanek@vsb.cz; petr.bora@vsb.cz

** Ing. Ph.D., Institute of Mining Engineering and Safety Faculty of Mining and Geology, VŠB - Technical University of Ostrava, Czech Republic, e-mail: milan.mikolas@vsb.cz 
organizations. It involves identifying, learning about, and adapting outstanding practices from organizations anywhere in the world in order to help your organization improve its sustainability program" (Pojasek 2010).

Benchmarking is not a new concept. It has been widely used since the 1970s. "Benchmarking has dramatically grown in popularity and use ever since the Xerox Group introduced the term to management at the end of the 1970s" (Karlof, Loevingsson 2005; Shah, Kleiner 2011).

However, the Xerox Group made a mistake common in managerial practice which Peter F. Drucker has described as "cream skimming". This concerned the appropriation of the most profitable section of the market. The Xerox Group concentrated on big consumers who bought many or expensive products.

The Xerox Group attempted maximization instead of optimization, which would have been a better alternative. Their customers' dissatisfaction finally led to a situation in which the Group was an easy target for Japanese imitators of Xerox's copiers (Drucker 2002).

The Japanese company Canon conducted a "simplified benchmarking". They compared the functionalities of Xerox's products and designed copiers that suited the individual needs of small consumers. Canon offered consumers what they really needed (Drucker 2002).

Benchmarking can also play a major role in meeting the needs of quality management. Total Quality Management (TQM) stresses the importance of managing quality with respect to all aspects of company life. In this context, benchmarking represents an integral part of strategic management. "There may be many reasons for carrying out benchmarking. The links based on industry best practice should directly contribute to better meeting of the internal and external customer requirements" (Oakland 1993).

The European Foundation for Quality Management (EFQM) model of excellence was based on benchmarking, and both models are based on the processes of human learning. The organisation, in the process of describing its own processes, learns what should be done to improve these processes (Fulmer, Goldsmith 2001).

In his book Benchmarking - mýty a skutečnost (Benchmarking - Myths and Reality), J. Nenadal has written, "Benchmarking can provide for a temporary competitive edge but only in conjunction with efficient and effective implementation of an improvement project" (Nenadál 2011). The prerequisite is to pay attention to the fact that "benchmarking is a process that should be initiated and supported by top management of the company that makes an effort to improve their performance" (Nenadál 2011).

Mineral extraction represents an important industry providing possibilities for many entrepreneurial initiatives that implicate specific risks (Vaněk et al. 2011).

The risks vary with respect to specific minerals. The Mineral Annual explains that in the recession year, 2009, the extraction of building stone, gravel, and sand decreased by about $70 \%$, though for lignite the decrease was only $5 \%$. Also a relatively low percentage decrease was seen in the extraction of limestone, totalling barely $15 \%$. The authors of this study 
have focused their interest especially on this raw material and the mining companies that produce it. In the Czech Republic, the limestone industry has an output of almost 10 million tons per year (Stary 2010) - Table 1.

The total reserves of limestone in the Czech Republic are in excess of 4.2 billion tons, which implies the possibility of a significant extraction initiative. The exploitation of this mineral offers a lot of entrepreneurial opportunities. The Mining Annual identified 20 companies which were active in this industrial sector in 2010 (Stary 2010). Table 2 gives data on the major extraction companies.

The extraction shares of the five companies listed in Table 2 amounted to almost $66 \%$ of the total extraction figure. This study's benchmarking has concerned just these five companies.

TABLE 1

Statistics for limestone production, 2005-2009

TABELA 1

Podstawowe dane o produkcji wapienia w latach 2005-2009

\begin{tabular}{|l|r|r|r|r|r|}
\hline \multicolumn{1}{|c|}{ Year } & \multicolumn{1}{c|}{2006} & \multicolumn{1}{c|}{2007} & \multicolumn{1}{c|}{2008} & \multicolumn{1}{c|}{2009} & \multicolumn{1}{c|}{2010} \\
\hline \hline Total reserves $[\mathrm{Gg}]$ & 4295554 & 4279084 & 4265039 & 4286327 & 4887573 \\
\hline Surveyed (balanced) $[\mathrm{Gg}]$ & 1699360 & 1755091 & 1742662 & 1762240 & 2082724 \\
\hline Prospected (balanced) $[\mathrm{Gg}]$ & 1804009 & 1778279 & 1777976 & 1777754 & 1934314 \\
\hline Non-balanced $[\mathrm{Gg}]$ & 792185 & 745714 & 744401 & 746333 & 870535 \\
\hline Extraction $[\mathrm{Mg}]$ & 10193 & 11279 & 10958 & 9117 & 9828 \\
\hline
\end{tabular}

Source: Starý 2010, 2012; authors' work

Major percentages concerning extraction of limestone in the Czech Republic

Procentowy udział przedsiębiorstw w całkowitym wydobyciu wapieni w Republice Czeskiej

\begin{tabular}{||l|c|c|}
\hline \multicolumn{1}{|c|}{ Mining company } & Extraction $[\mathrm{Mg}]$ & Share [\%] \\
\hline \hline Českomoravský cement, a.s. & 2020936 & 19.60 \\
\hline Cement Hranice, a.s. & 885170 & 8.58 \\
\hline LOMY MOŘINA, spol. s r. o & 1123030 & 10.89 \\
\hline Holcim (Česko) a.s., Concern Member & 802500 & 7.78 \\
\hline Velkolom Čertovy schody, a.s. & 1931112 & 18.72 \\
\hline Others & 3550269 & 34.43 \\
\hline Total & 10313017 & 100.00 \\
\hline
\end{tabular}

Source: Mining Annual, authors' work 


\section{Benchmarking as a model}

Many models for benchmarking exist. Many of them represent variations of a common approach. Of these, the Robert C. Camp's model is most often applied. This study has also taken advantage of the Camp model. The authors used Robert C. Camp's model performed by Robert G. Gift and Catherine F. Kinney (Fig. 1).

\begin{tabular}{|c|c|c|c|}
\hline & \multirow[b]{2}{*}{ Phase 1. Planning } & Step 1. & Identify benchmarking subject \\
\hline \multirow[b]{5}{*}{ Benchmarking } & & Step 2. & Identify benchmarking partner \\
\hline & \multirow[b]{3}{*}{ Phase 2. Analysis } & Step 3. & Identify benchmarking method \\
\hline & & Step 4. & Determine the performance gap \\
\hline & & Step 5. & Project future performance \\
\hline & \multirow[b]{2}{*}{ Phase 3. Integration } & Step 6. & Communicate results \\
\hline \multirow[t]{5}{*}{ Model } & & Step 7. & Establish functional goals \\
\hline & \multirow[b]{2}{*}{ Phase 4. Action } & Step 8. & Develop action plans \\
\hline & & Step 9. & Implement plans; monitor results \\
\hline & \multirow[b]{2}{*}{ Phase 5. Maturity } & Step 10. & Recalibrate benchmarks \\
\hline & & Step 11. & Integrate benchmarking \\
\hline
\end{tabular}

Fig. 1. Benchmarking Model

Sources: Gift, Kinney 1996; authors' work

Rys. 1. Model benchmarkingowy

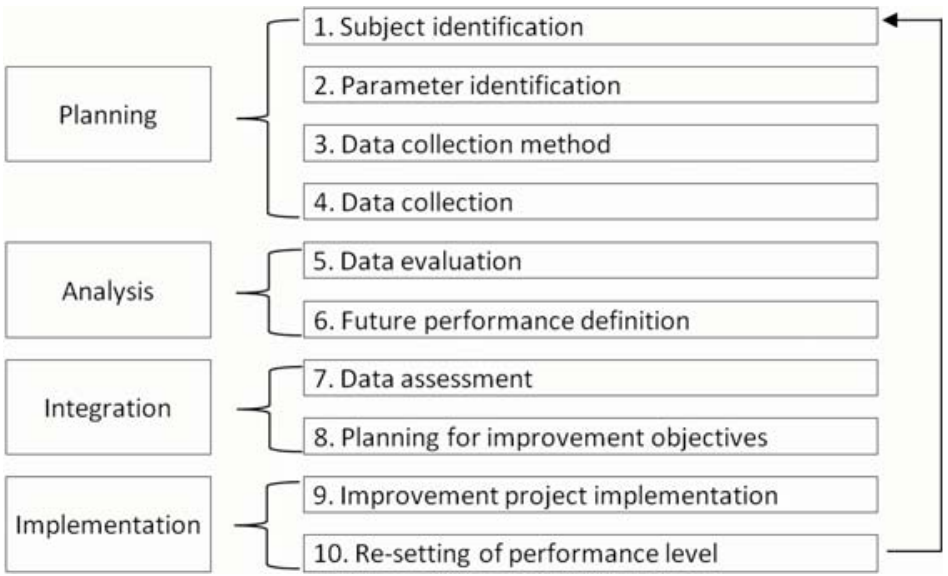

Fig. 2. Substantial phases of benchmarking according to Xerox Corp Sources: Nenadal 2011; authors' work

Rys. 2. Podstawowe etapy benchmarkingu według firmy Xerox Corp 
Figure 1 shows eleven formal steps for making comparisons that are structured in five phases planning, analysis, integration, action, and maturity. The following subsections elaborate on those phases (Gift, Kinney 1996).

No standards (algorithms, methods) for benchmarking exist, making its application difficult. No unified framework or procedure has been defined to provide for individual measurements and comparison. The number of individual phases, steps, and key activities vary considerably. The most common benchmarking models imply seven to ten phases (Nenadal 2011).

As already mentioned, the Xerox Corp. conducted the first benchmarking ever. Led by manager Robert Camp, Xerox conducted a systematic analysis of what its competitors (and other companies) were doing well, and how. They employed phases illustrated by Figure 2. This is a good example of what is significant for any benchmarking process (Shapiro 1999).

\subsection{Planning}

Integral to any benchmarking efforts are processes and activities. The subject of comparison should be defined first. Theoretically, this can be any characteristic, feature, or parameter concerning products, services, or even operations of the whole company; but a basic rule must be observed the subject of benchmarking is that which has been objectively identified and confirmed as one's own weakness.

There can be grave consequences if certain rules are ignored for benchmarking's objective selection. Wrong benchmarking subject identification can gravely affect all consecutive phases of its execution (Nenadal 2011). If this has been provided for, "then the organization must determine how it will collect data from the companies it is benchmarking against" (Gift, Kinney 1996).

\subsection{Analysis}

The analytical phase of benchmarking concerns assessments of data on a competitor's performance, analysing performance differences by appropriate methods. In Gift's words, "Phase 2 of the benchmarking model assesses the gap between current performance and best practice" (Gift, Kinney 1996).

We should realize that data lacking assessment are just sets of meaningless letters and numbers of no real value. Phase 2 structures the data gathered so that performance differences can be specified. This may concern the company's overall performance or features of individual products or services.

The data processing should be preceded by:

1) Data classification and structuring.

2) Data quality authentication.

3) Exclusion of data non-comparable factors that influenced their gathering. 
For benchmarking, if such non-comparable factors have been identified, they should be discarded. Performance data that have been tainted by such factors should be re-assessed and re-calculated.

This analysis results in defining a benchmark representing a performance level in need of improvement (Nenadal 2011).

\subsection{Integration}

At this stage, top managers are informed about the results of benchmarking analysis. The integration phase of benchmarking commences in which individual performance improving measures are implemented by upper level managers or their nominees as shown in Figure 3 (Nenadal 2011).

"In the integration phase, the organization refines its goals and incorporates them into its planning process" (Gift, Kinney 1996).



Fig. 3. Benchmarking integration sequence Source: Nenadal 2011

Rys. 3. Kolejność procesów obliczeniowych w procesie benchmarkingu

\subsection{Implementation}

Based on the benchmarking results, specific road-maps for improvement implementations are developed. They are the last phase of the benchmarking process to be realized. This road-map development is fully at the discretion of the organisation itself (Nenadal 2011).

The benchmarking implementation phase can take advantage of applying commonly acknowledged methods such as Deming's PDCA. Deming introduced PDCA to Japanese enterprises in 1950. According to this methodology, quality improvements take place through four major steps Plan-Do-Check-Action (Oakland 1993; Shah 2011).

"The form of management style and corporate culture outlined here is the antithesis of the traditional management style operating in a hierarchical organizational structure, which tends to exert authoritarian control and to restrict power, information, and privilege. In particular, it inhibits the effective use of a central feature of the operation of a total quality approach, that is, teamwork" (Stuart 1996). 


\section{Method}

There exist many specific methods that can be applied for purposes of benchmarking comparisons. Where companies are concerned, the economic and financial situation can be analysed by many differentials and ratios, but they reflect only a relatively isolated section of a company's overall activities. To be able to assess the whole, differentials and ratios are structured into analytical systems. Nevertheless, the latter, consisting of myriads of items, does not provide for a clear picture of a company's competitive performance. To solve this problem, models have been developed that yield just one parameter (assessment coefficient, synthetic indicator) (Sedlacek 2011).

There exist parameter systems that have been built from specifically selected indicators. The systems are put together by applying comparative/analytical or mathematical/statistical methods. The objective is to provide for such indicators that would satisfactorily diagnose the financial situation (financial health) of the organisation or predict the risk of failure (financial distress), if any exists. For this purpose, these parameter systems are structured as Site Valuation (diagnostic) and Default (predictive). After such systems have been provided for, they are adopted as models (Sedlacek 2011).

One of the methods applied is the method of standard variable, which is integral to the site assessment model. This model tries to define the financial situation of an organisation by employing just one synthetic parameter or at most a very limited number (Sedlacek 2011).

The standardized variable method is applicable to any set of statistical data for comparison. In this case, the statistical data set consists of equations of ratios used in Financial Analysis.

Parameters like ROE, profit margin, asset turnover, and total costs are constituents of hierarchical (pyramidal) structures that can identify logical and economic relations between individual ratios by analyzing their structure. An example of a pyramidal structure is the ROE analysis first developed and utilized by the international corporation Du Pont de Nemours (Sedlacek 2011).

\subsection{Standard variable method}

The standard variable method solves the biggest problem of other mathematical/statistical methods, namely insensitivity to error variance. That is why this method yields results less sensitive to parameter extremes (Sedlacek 2011).

The application of the method provides for a hierarchical order of organisations according to their arithmetic averages (calculated standard values) and weighted averages that have been calculated using the values of differentiated weights (Sedlacek 2011).

The best organisation is rated 1 , the next $n+1$, down to the worst organisation indicated by $\mathrm{n}+i$ (Sedlacek 2011).

If compared, the individual ratios can be weighted to express their significance in relation to the item analysed. Then, a matrix is formed consisting of ratios and values valid for the period analysed. 
The best practice ratios are used for structuring the matrix. ROE, profit margin, profitability, LTA productivity, labour productivity, and asset turnover were applied in our matrix.

The original ratios, $x_{i j}$, are transformed in accordance with the standard variable theory to provide for standard variables $u_{i j}$ (Sedlacek 2011).

The transformation of ratios, $x_{i j}$ to $u_{i j}$, regarding ratio characteristics, +1 (plus two) is executed using formula 1 (Sedlacek 2011):

$$
u_{i j}=\frac{x_{i j}-x_{p j}}{s_{x j}}
$$

where:

$x_{i j}-$ ratio $j$, of organisation $i$,

$x_{p j}-$ arithmetic average calculated from ratio $j$,

$s_{x j}-$ standard deviation calculated from ratio $j$.

The ratio $x_{i j}$ is transformed to a standard variable, $u_{i j}$, regarding ratio characteristics, -1 (minus one) by formula 2 (Sedlacek 2011):

$$
u_{i j}=\frac{x_{p j}-x_{i j}}{s_{x j}}
$$

The integral ratio, $d_{4 i}$, is calculated as a weighted arithmetic mean using standard variables calculated for individual ratios of the organisation $i$, formula 3 (Sedlacek 2011):

$$
d_{4 i}=\frac{\sum_{j=1}^{m} u_{i j} \cdot p_{j}}{\sum_{j=1}^{m} p_{j}}
$$

where:

$$
\begin{aligned}
& p_{j}-\text { weight of ratio } j, \\
& u_{i j}-\text { transformed ratio. }
\end{aligned}
$$

\subsection{Weight specification - Fuller's method}

The benchmarking information's value can be increased if the ratios of comparison are weighted. This can be done in many different ways. We have decided to use Fuller's method (or Fuller's triangle). 
This method's advantage is the fact that - if many ratios are compared - it allows for comparison between only two ratios in order to decide which of them is more significant. It is a pair comparison model (Fiala 2008; Fotr 2010).

The method is as follows:

1. Ratio pairs are entered into the Fuller's triangle, the preferred constituents of each pair bold labelled.

2. The number of preferences for each ratio is counted.

3. Each ratio preference number is divided by the number of all comparisons made, providing the weights.

A disadvantage of this method is that zero weight ratios are not necessarily of zero significance. This disadvantage can be excluded by adding 1 to each ratio preference number (Fiala 2008; Fotr 2010).

\section{Benchmarking Applied to Certain Limestone Mining Companies}

For comparing the choices of mining companies, this study applied the aforementioned method and principles. Nevertheless, the main focus was on the first two benchmarking phases, i.e. planning and analysis.

\subsection{Subject identification}

This study's interest concentrated on a sample of limestone producing companies. A limestone companies' production must have been in excess of 800 thousand tons annually (2010, Mining Annual 2012) to classify for benchmarking. Only 5 companies fell within this classification criterion, as mentioned in the introduction chapter of this paper. The production of these companies amounts to $66 \%$ of total limestone production in the Czech Republic. As such, the subjects of this study's benchmarking initiative were as follows:

- Českomoravský cement a.s., operating in two separate localities of Radotin, Prague, and Mokra, near Brno.

- Cement Hranice, a.s. until 2004, a member of the Italian concern Buzzi Unicem. It produces mainly cement and mortar binding agents. The limestone production takes place in mining areas of Hranice and Cernotin.

- LOMY MOŘINA spol. s. r. o. Currently the company operates three quarries: (1) Quarry of Cerinka located at the northern part of the anticlinal fold of Doutnace. This limestone is mainly used for power station desulphurization purposes; (2) Quarry of Holy Vrch located in the southern part of the anticlinal fold of Amerika. The limestone produced is only suitable for making aggregate; (3) Quarry of Tetin located at the left bank of the river, Berounka. The limestone of this site is suitable for more demanding purposes due to its purity and carbonate content. 
- Holcim (Česko) a.s. This company is a major producer of cement, aggregate, and concrete, and provides services related to its production. The company operates in the mining area of Prachovice.

- Velkolom Čertovy schody, a.s. The company operates in a district of Beroun where limestone has been extracted for more than one thousand years. The quarries operate on a large scale industrial level producing limestone and sialic additives, as well as other limestone-based products. The extraction is executed at two sites, the mining areas of Koneprusy and Suchomasty.

\subsection{Benchmarking parameter identification}

Those parameters were identified which were needed by the model for comparison of individual mining companies namely, financial and operational data that are part of the ratio parameters. For example, these include the financial ratios of ROE and profit margin or operational ratios of cost efficiency, $\mathrm{LTA}^{1}$, and labour productivities. The last ratio is that of overall activity asset turnover. Table 3 gives the ratio overview and designations.

TABLE 3

Ratios designation

TABELA 3

Wykaz wskaźników

\begin{tabular}{|c|c|c|c|}
\hline \multirow[t]{2}{*}{ Ratio } & \multicolumn{2}{|c|}{ Financial ratio } & Operational ratio \\
\hline & $\begin{array}{c}\text { Return on equity } \\
= \\
\text { Profit/Internal capital }\end{array}$ & $\begin{array}{c}\text { Profit margin } \\
= \\
\text { (Revenue-Cost)/Revenue }\end{array}$ & $\begin{array}{c}\text { Cost efficiency } \\
= \\
\text { Cost } / \text { Revenue }\end{array}$ \\
\hline Designation & $\mathrm{K}_{1}$ & $\mathrm{~K}_{2}$ & $\mathrm{~K}_{3}$ \\
\hline \multirow[t]{2}{*}{ Ratio } & Activity ratio & \multicolumn{2}{|c|}{ Operational ratios } \\
\hline & $\begin{array}{c}\text { Total assets return } \\
= \\
\text { Revenue/Asset }\end{array}$ & $\begin{array}{c}\text { Fixed assets productivity } \\
= \\
\text { Revenue/Fixed assets }\end{array}$ & $\begin{array}{c}\text { Labour productivity } \\
= \\
\text { Production volume/Staff number }\end{array}$ \\
\hline Designation & $\mathrm{K}_{4}$ & $\mathrm{~K}_{5}$ & $\mathrm{~K}_{6}$ \\
\hline
\end{tabular}

Source: authors' work

\subsection{Data collection method}

This study has utilized the most commonly applied method for drawing data from certified sources of free access namely, financial sections of documents published by the companies that were subjects of this benchmarking initiative.

1 LTA - Long-lived (tangible) assets: Long-lived assets are those that a business retains for long periods for use in the course of normal operations rather than for sale. They may be divided into tangible assets (land, buildings, and equipment) and intangible assets (including goodwill, patents, and franchises). 
Weights of ratios

TABELA 4

Ustanowienie wag dla wskaźników

\begin{tabular}{|c|c|c|c|c|c|}
\hline \hline Design. & $\begin{array}{c}\text { Number of } \\
\text { preferences }\end{array}$ & Weight & $\begin{array}{c}\text { New number of } \\
\text { preferences }\end{array}$ & $\begin{array}{c}\text { Adjusted } \\
\text { weight }\end{array}$ & $\begin{array}{c}\text { Adjusted } \\
\text { weight }\end{array}$ \\
\hline \hline $\mathrm{V}_{1}$ & 5 & $1 / 3$ & 6 & $2 / 7$ & $28.57 \%$ \\
\hline $\mathrm{V}_{2}$ & 3 & $1 / 5$ & 4 & $4 / 21$ & $19.05 \%$ \\
\hline $\mathrm{V}_{3}$ & 4 & $1 / 4$ & 5 & $5 / 21$ & $23.81 \%$ \\
\hline $\mathrm{V}_{4}$ & 0 & 0 & 1 & $1 / 21$ & $4.76 \%$ \\
\hline $\mathrm{V}_{5}$ & 1 & $1 / 15$ & 2 & $2 / 21$ & $9.52 \%$ \\
\hline $\mathrm{V}_{6}$ & 2 & $2 / 15$ & 3 & $1 / 7$ & $14.29 \%$ \\
\hline Total & 15 & 1 & 21 & 1 & $100.00 \%$ \\
\hline
\end{tabular}

Source: authors' work

TABLE 5

Original data of benchmarking, 2010

TABELA 5

Dane wyjściowe w badaniach benchmarkingowych - 2010

\begin{tabular}{||l|c|c|c|c|c|}
\hline \multirow{2}{*}{ Value (CZK thousand) } & \multicolumn{5}{|c|}{ Company } \\
\cline { 2 - 7 } & $\begin{array}{c}\text { Cement } \\
\text { Hranice }\end{array}$ & $\begin{array}{c}\text { Holcim } \\
\text { Česko }\end{array}$ & $\begin{array}{c}\text { LOMY } \\
\text { MOŘINA }\end{array}$ & $\begin{array}{c}\text { Velkolom } \\
\text { Čertovy schody }\end{array}$ & $\begin{array}{c}\text { Českomoravský } \\
\text { cement }\end{array}$ \\
\hline \hline Assets & 1990536 & 2842767 & 412443 & 250494 & 7016696 \\
\hline Internal capital & 1431679 & 795072 & 363469 & 201604 & 5271623 \\
\hline Profit & 453314 & 149002 & 219 & 1815 & 1055006 \\
\hline Revenues & 1553982 & 1980484 & 212700 & 112371 & 3484029 \\
\hline Costs & 1272619 & 2099125 & 216604 & 112086 & 3090219 \\
\hline Revenue & 1725933 & 2248127 & 216823 & 113901 & 4145225 \\
\hline Revenue (only regular) & 1725933 & 2248127 & 216823 & 113901 & 4145225 \\
\hline LTA in PPs* & 1114235 & 2594783 & 277477 & 150333 & 5752916 \\
\hline Profit check & 453314 & 149002 & 219 & 1815 & 1055006 \\
\hline Production volume [Mg] & 885170 & 802500 & 1123030 & 1931112 & 2020936 \\
\hline Staff [persons] & 15 & 65 & 39 & 21 & 47 \\
\hline
\end{tabular}

* Long-lived (tangible) assets in Purchase prices.

Source: Company Annual Reports; authors' work 


\subsection{Data collection}

The Annual Reports of the companies of this study's benchmarking initiative and the Mining Annuals, 2008, 2009, 2010, provided the necessary data.

\subsection{Analys is}

The data assessment was conducted by analyses of a financial character. A mathematical/ /statistical variant of the financial analysis was chosen for this purpose the method of standard variable that provides for classification of subjects from the best to the worst.

First, the weights were attributed to individual ratios. As already mentioned, the method of Fuller's triangle was applied. Results are given by Table 4.

TABLE 6

Benchmarking ratios, 2008-2010

TABELA 6

Wartości wyznaczonych wskaźników w badaniach benchmarkingowych, 2008-2010

\begin{tabular}{|c|c|c|c|c|c|c|c|c|c|}
\hline \multirow{2}{*}{ Company } & \multicolumn{3}{|c|}{ K1 } & \multicolumn{3}{|c|}{ K2 } & \multicolumn{3}{|c|}{ K3 } \\
\hline & 2008 & 2009 & 2010 & 2008 & 2009 & 2010 & 2008 & 2009 & 2010 \\
\hline 1. & $46.6 \%$ & $38.5 \%$ & $31.7 \%$ & $36.9 \%$ & $34.6 \%$ & $29.2 \%$ & $68.8 \%$ & $70.3 \%$ & $73.7 \%$ \\
\hline 2. & $35.7 \%$ & $24.9 \%$ & $18.7 \%$ & $10.1 \%$ & $9.9 \%$ & $7.5 \%$ & $91.7 \%$ & $91.4 \%$ & $93.4 \%$ \\
\hline 3. & $0.2 \%$ & $0.2 \%$ & $0.1 \%$ & $0.3 \%$ & $0.4 \%$ & $0.1 \%$ & $99.7 \%$ & $99.6 \%$ & $99.9 \%$ \\
\hline 4. & $0.9 \%$ & $0.9 \%$ & $0.9 \%$ & $1.6 \%$ & $1.7 \%$ & $1.6 \%$ & $98.5 \%$ & $98.6 \%$ & $98.4 \%$ \\
\hline 5. & $48.4 \%$ & $33.0 \%$ & $20.0 \%$ & $34.2 \%$ & $42.3 \%$ & $30.3 \%$ & $72.2 \%$ & $66.7 \%$ & $74.5 \%$ \\
\hline Character & \multicolumn{3}{|c|}{1} & \multicolumn{3}{|c|}{1} & \multicolumn{3}{|c|}{-1} \\
\hline Weight & \multicolumn{3}{|c|}{$28.57 \%$} & \multicolumn{3}{|c|}{$19.05 \%$} & \multicolumn{3}{|c|}{$23.81 \%$} \\
\hline \multirow{2}{*}{ Company } & \multicolumn{3}{|c|}{ K4 } & \multicolumn{3}{|c|}{ K5 } & \multicolumn{3}{|c|}{ K6 } \\
\hline & 2008 & 2009 & 2010 & 2008 & 2009 & 2010 & 2008 & 2009 & 2010 \\
\hline 1. & $235.8 \%$ & $179.7 \%$ & $154.9 \%$ & $235.8 \%$ & $179.7 \%$ & $154.9 \%$ & 73434.706 & 55914.824 & 59011.333 \\
\hline 2. & $116.5 \%$ & $98.8 \%$ & $86.6 \%$ & $116.5 \%$ & $98.8 \%$ & $86.6 \%$ & 20716.049 & 18166.667 & 12346.154 \\
\hline 3. & $81.5 \%$ & $75.4 \%$ & $78.1 \%$ & $81.5 \%$ & $75.4 \%$ & $78.1 \%$ & 40894.250 & 47116.667 & 28795.641 \\
\hline 4. & $103.9 \%$ & $83.1 \%$ & $72.1 \%$ & $103.9 \%$ & $83.1 \%$ & $72.1 \%$ & 607190.000 & 85599.150 & 91957.714 \\
\hline 5. & $77.8 \%$ & $77.2 \%$ & $75.8 \%$ & $77.8 \%$ & $77.2 \%$ & $75.8 \%$ & 50454.9020 & 44652.174 & 42998.638 \\
\hline Character & \multicolumn{3}{|c|}{1} & \multicolumn{3}{|c|}{1} & \multicolumn{3}{|c|}{1} \\
\hline Weight & \multicolumn{3}{|c|}{$4.76 \%$} & \multicolumn{3}{|c|}{$9.52 \%$} & \multicolumn{3}{|c|}{$14.29 \%$} \\
\hline
\end{tabular}

Source: authors' work

1. - Cement Hranice, a. s., 2. - Holcim Cesko, a. s., 3. - LOMY MORINA spol. s.r.o., 4. - Velkolom Certovy schody, a. s., 5. - Ceskomoravský cement, a.s. 
Table 5 gives original data for calculations of comparison ratios. The overview of these ratios is given by Table 6 .

A characteristic number was attributed to the ratios calculated. The number's positive or negative value denotes whether ratio growth or rather its decrease is needed for a company's improved performance:

- if ratio growth is necessary, +1 is attributed,

- if a ratio decline is needed, -1 is attributed.

Table 6 gives both the character and the weight of ratios. The next step is the transformation of the values by formulas $1-3$ as shown in Table 7 .

TABLE 7

Ratio transformation - Standard variable method

Przekształcenia wartości wskaźników - metoda normowania zmiennych

\begin{tabular}{||l|c|c|c|c|c|c||}
\hline \multirow{2}{*}{ Company } & \multicolumn{2}{c|}{2008} & \multicolumn{2}{c|}{2009} & \multicolumn{2}{c|}{2010} \\
\cline { 2 - 8 } & Average & Rating & Average & Rating & Average & Rating \\
\hline \hline Cement Hranice, a. s. & 1.0450 & 1. & 1.0261 & 1. & 1.1568 & 1. \\
\hline Holcim Cesko, a. s. & -0.0416 & 3. & 0.0638 & 3. & -0.1810 & 3. \\
\hline LOMY MORINA spol. s.r.o. & -0.7095 & 5. & -0.4854 & 4. & -0.7375 & 5. \\
\hline Velkolom Certovy schody, a. s. & -0.7084 & 4. & -0.4895 & 5. & -0.7207 & 4. \\
\hline Ceskomoravský cement, a.s. & 0.6998 & 2. & 0.3982 & 2. & 0.4847 & 2. \\
\hline & by differentiated weights & & & \multicolumn{2}{|c|}{} \\
\hline Cement Hranice, a. s. & 0.9512 & 1. & 0.9062 & 1. & 1.1166 & 1. \\
\hline Holcim Česko, a. s. & -0.0822 & 3. & -0.1944 & 3. & -0.2317 & 3. \\
\hline LOMY MOŘINA spol. s.r.o. & -0.4872 & 4. & -0.3521 & 4. & -0.5126 & 4. \\
\hline Velkolom Čertovy schody, a. s. & -0.7707 & 5. & -0.6255 & 5. & -0.7520 & 5. \\
\hline Ceskomoravský cement, a.s. & 0.8974 & 2. & 0.8055 & 2. & 0.7129 & 2. \\
\hline
\end{tabular}

Source: authors' work

The particular computations of the standard variable method are not published owing to the lack of space. Table 7 shows aggregate dates.

The last step of the benchmarking was rating of the companies. To clarify, this study presents the results of the benchmarking graphically, in Figure 4. 
170

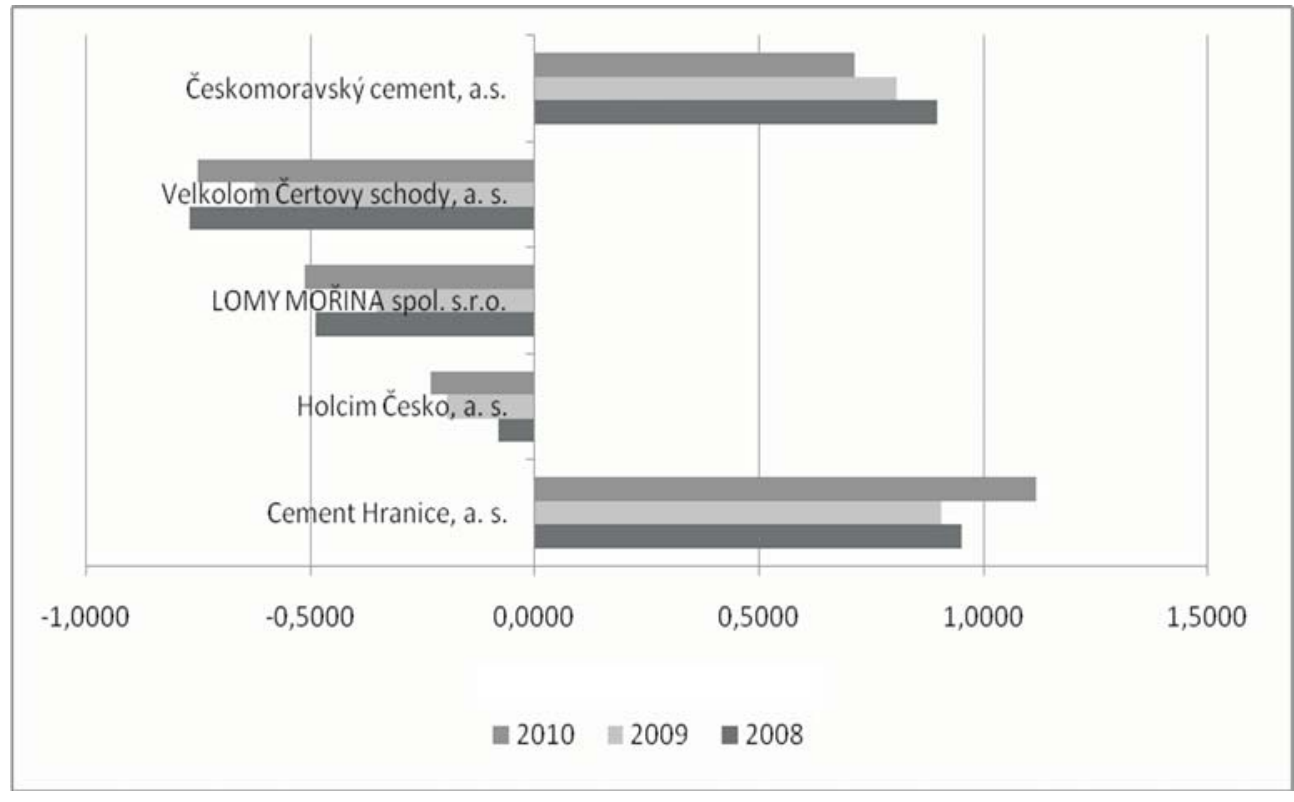

Fig. 4. Benchmarking graphics, 2008-2010

Source: authors' work

Rys. 4. Ranking przedsiębiorstw w latach 2008-2010

\section{Conclusions}

In the period 2008-2010, the Cement Hranice, a.s. received the best rating of the sample and Velkolom Certovy schody, a.s. received the worst.

Looking closer, one realises that the best ROE $\left(\mathrm{K}_{1}\right)$ was shown by Ceskomoravsky cement, a.s. Nevertheless, this ratio was decreasing more rapidly over the years than was the case for Cement Hranice, a.s. the main competitor. Although in the same period the ROE ratio of Cement Hranice also decreased, this decrease was not as dramatic as was the case for Velkolom Certovy schody, a.s. and LOMY MORINA spol. s.r.o. These companies received ratings close to $1 \%$.

Revenue profitability $\left(\mathrm{K}_{2}\right)$ of these two companies was again very low in comparison to other subjects of the sample. With regards to this ratio, the company Ceskomoravsky cement, a.s. was by far the best. In 2009, it received the highest rate of $42.3 \%$. Nevertheless, the company Cement Hranice, a.s. could have received almost as good a rating at between 29.2 and $36.9 \%$.

The cost efficiency ratios $\left(\mathrm{K}_{3}\right)$ were more or less the same for all subjects of the benchmarking sample. That is why this ratio did not influence the rating of any subject. 
It may be the case that these results are the same for the whole limestone extraction industry in the Czech Republic.

Considering the ratio of asset return $\left(\mathrm{K}_{4}\right)$, again Cement Hranice, a.s. was the clear winner. This is due to the fact that this company concentrates on production of valuable cement implying higher prices, which is reflected in the final revenue figures. The company Holcim Cesko, a.s. was [only next (meaning unclear)] and could outdo Ceskomoravsky cement, a.s. which had usually been in second place.

As far as the ratio revenue/LTA $\left(\mathrm{K}_{5}\right)$ is concerned, Cement Hranice, a.s. could receive the best rating because it also produces valuable cement. The other subjects of the sample received more or less the same rating figures.

The productivity ratio figures $\left(\mathrm{K}_{6}\right)$ were relatively the same for all subjects compared. As such, the final rating was dominantly influenced by ROE and profit margins. There, the clear losers were Velkolom Certovy schody, a.s. and LOMY MORINA spol. s r. o., which fundamentally influenced their low final benchmarking rating.

To say why these companies were so unsuccessful, a deeper analysis of their financial and assets standing is necessary.

The analytical part of benchmarking is followed by benchmarking's next two phases integration and implementation items, points $6-10$ of the method. These items concern individual subjects of the sample. The objective of these two phases is to provide for improvement of the current status. It is obvious that they require provisions for further analytical steps a task which can be addressed only by an internal benchmarking team. This study could not provide such analysis without access to sensitive, internal company information. Nevertheless, the authors of this study assert that even lacking these final benchmarking phase provisions, the results of this benchmarking initiative has been informative and interesting not only for managers of the benchmarked companies but also for a wider expert public.

\section{REFERENCES}

Drucker F.P., 1999 - Mangement Challenges for Managers of 21st Century. 1st Edition. New York: HarperCollins Publishers Inc.

Drucker F.P., 2002 - To nejdůležitější z Druckera v jednom svazku (The Most Important of Drucker in One Volume). Praha: Management Press.

F i a la P., 2008 - Modely a metody rozhodování (Decision-Making Models and Methods). Praha, Oeconomica. F o tr J., 2003 - Manažerské rozhodování (Managerial Decision-Making), Dědina J., Hrůzová H., Praha, Ekopress. Fotr J., 2010 Manažerské rozhodování: postupy, metody a nástroje (Managerial Decision-Making: Procedures, Methods and Tools). Praha, Ekopress.

F u 1 m e r R.M., 2001 - Goldsmith, Marshall. The leadership investment: how the world's best organizations gain strategic, Appendix A: Benchmarking - The Systematic Transfer of Best Practices. USA, AMACOM.

G ift R.G., K in n e y C.F., 1996 - Today's Management Methods: A Guide for the Health Care Executive. USA, Jossey-Bass.

Karlof Bengt, Loevingsson H.F., 2005 - The A-Z of Management Concepts and Models. London, Thorogood Publishing. 
Hornická ročenka (Mining Annual) 2008, 2009 - Ostrava, Montanex.

Hornická ročenka (Mining Annual) 2009, 2010 - Ostrava, Montanex.

Hornická ročenka (Mining Annual) 2010, 2011 - Ostrava, Montanex.

Nenadál J., 2011 - Benchmarking - mýty a skutečnost (Benchmarking - Myths and Reality), Vykydal D., Halfarová P., Praha, Management Press.

O a kl and S.J., 1993 - Total quality management: the route to improving performance: 2nd ed., Great Britain.

P oj a s e k B.R., 2010 - Benchmarking to sustainability in four steps.. Environmental Quality Management, United States, vol. 20, Issue 2, p. 87-94, DOI: 10.1002/tqem.20282.

S e dlá č e k J., 2011 - Finanční analýza podniku (Company Financial Analysis), Brno: Computer Press.

Sh a p iro E., 1999 - Fast-cycle benchmarking. Harvard Management Update, UNITED States: Harvard Business Publishing Newsletters, vol. 4. Issue 4, p1, 4p. Business Source Complete.

Shah D., Kleiner H.B., 2011 - Industrial Management, Benchmarking for quality, Vol. 53, Issue 2, p. 22-25, 4p, 1 Color Photograph, 2 Diagrams. EBSCO Information Services - Business Source Complete, Copyright of Industrial Management is the property of Institute of Industrial Engineers.

S t a rý J., 2010 - Surovinové zdroje České republiky: nerostné suroviny 2010 (Mineral Resources of the Czech Republic, 2010), statistické údaje do roku 2009 (Statistics until 2009). Praha, Ministerstvo životního prostředí ČR.

S t a rý J., 2012 - Surovinové zdroje České republiky: nerostné suroviny 2011(Mineral Resources of the Czech Republic, 2011), statistické údaje do roku 2010 (Statistics until 2010). Praha, Ministerstvo životního prostředí ČR.

Stuart Michael, Mullins Eamonn, Drew Eileen, Statistical quality control and improvement, European Journal of Operational Research, 1996, Vol. 88, Issue 2, Pages 203-214. EBSCO Information Services - Business Source Complete

V a něk M., Mikoláš M., Růčk ová H., B a r toňová J., K uče rová L., 2011 - Žoček, František. Analysis of Mining Companies Operating in the Czech Republic in the Sector of Non-metallic and Construction Minerals. Gospodarka Surowcami Mineralnymi t. 27, z. 4, s. 17-32.

\section{BENCHMARKING NAJWIEKSZYCH PRODUCENTÓW WAPIENI W REPUBLICE CZESKIEJ}

\section{Słowa kluczowe}

Benchmarking, spółki górnicze, wapienie, Republika Czeska

\section{Streszczenie}

Jakość podejmowania decyzji, a tym samym właściwe zarządzanie przedsiębiorstwem, jest ściśle związane z pozyskiwaniem ważnych informacji, którymi powinno dysponować kierownictwo firmy. Jedną z metod pozyskiwania takich ważnych informacji jest benchmarking. Znaczenie benchmarkingu jest na tyle ważne, że coraz więcej badaczy włącza go jako obowiązkową część składową działalności przedsiębiorstwa. W sferze gospodarki występują jednak trudności z wykorzystaniem tej metody zarządzania z powodu tajemnicy prawa handlowego. Szeroka grupa fachowców jest więc pozbawiona cennych informacji. Nasze opracowanie ma na celu przyspieszenie zmiany tej sytuacji wprowadzając zasady i pokazując efekty benchmarkingu dla wybranych spółek wydobywających wapienie.

W ramach benchmarkingu wybrano największe spółki górnicze w Republice Czeskiej zajmujące się eksploatacją wapieni. Wybrane spółki obejmują obecnie 66\% rynku. Wybrano więc: Ceskomorawsky cement a.s.; Cement Hranice a s.; LOMY MORINA, spol.s r. o; Holcim (Cesko) a. s., członek koncernu ; Velkolom Certovy schody, a. s.

Podstawą badań benchmarkingu były wskaźniki finansowe (ROE, stopa zysku) i produkcyjne (koszty, wielkość produkcji DHM, wydajność pracy). Obliczenia tych wskaźników prowadzono dla lat 2008-2010. Ocena danych wykonywana była na podstawie analizy finansowej. Do przeprowadzenia analizy finansowej wybrano 
metodę matematyczno-statystyczną. Zastosowano metodę normowania zmiennych, której rezultatem było utworzenie rankingu przedsiębiorstw od najlepszego do najgorszego.

Wykazano, że znaczenie benchmarkingu można zwiększyć przydzielając wskaźnikom, za pomocą których badany jest obiekt przemysłowy, odpowiednie wagi, zmieniające rangę wybranych wskaźników. W obliczeniach autorzy zdecydowali się zastosować metody Fulliera, a konkretnie trójkąt Fulliera.

W dużej liczbie badanych przedsiębiorstw wydobywczych spółki „Cement Hranice” w podanym wyżej okresie oka, w najgorszej sytuacji znajdowało się przedsiębiorstwo Velkolom Certovy schody a.s.

\section{BENCHMARKING FOR MAJOR PRODUCERS OF LIMESTONE IN THE CZECH REPUBLIC}

$$
\text { Key words }
$$

Benchmarking, limestone producers, Czech Republic, financial ratios

\section{Abstract}

The validity of information available to managers influences the quality of the decision-making processes controlled by those managers. Benchmarking is a method which can yield quality information. The importance of benchmarking is strengthened by the fact that many authors consider benchmarking to be an integral part of strategic management. In commercial practice, benchmarking data and conclusions usually become commercial secrets for internal use only. The wider professional public lacks this valuable information. This paper tries to fill the gap regarding the operation of certain limestone extraction companies. It presents information and conclusions drawn from an independent benchmarking investigation.

This study focused on major limestone producers in the Czech Republic which export their product abroad. These producers' domestic market share is almost $66 \%$. Specifically, the following companies were subjects of this benchmarking analysis: Českomoravský cement, a.s.; Cement Hranice, a.s.; LOMY MOŘINA, s.r.o.; Holcim (Česko) a.s.; and Velkolom Čertovy schody, a.s.

The financial (ROE, profit margin) and production (return-on-investment, LTA, and labour productivity) ratios were the benchmarking's starting point. These ratios were from company performance during the period 2008-2010. The mathematical and statistical methods of financial analyses provided for the data assessments namely, the standard variable method. The application of this method yielded results rating limestone producers in a best-to-worst sequence.

The benchmarking information's value can be increased if the ratios are weighted, which expresses the significance of individual ratios. This study applied the Fuller's triangle method.

Concerning the producers investigated, Cement Hranice, a.s. has been the best performer, and Velkolom Certovy schody, a.s. the worst. 
